\title{
The Role and Significance of Bcl-2 and Bax in the Hepatic Carcinoma
}

\author{
El Rol y la Importancia de Bcl-2 y Bax en el Carcinoma Hepático
}

\author{
"Liu Hongfu; "Zhang Luping; "Chen Shaojie; "Wang Zengxian; "Huang Fei \& *Wang Dong
}

LIU, H.; ZHANG, L.; CHEN, S.; WANG, Z.; HUANG, F. \& WANG, D. The role and significance of Bcl-2 and Bax in the hepatic carcinoma. Int. J. Morphol., 30(4):1466-1473, 2012.

SUMMARY: This study aimed to observe the regularity of liver cell apoptosis and expression of apoptosis related gene Bcl-2 and $\mathrm{Bax}$ in the induced cancer, and explore the relationship between apoptosis and the development of liver cancer. In this study, 84 rats were used, 72 rats as experimental group induced by drinking water containing DEN, 12 rats as control group (CG). After laparotomy, the form, color, texture of the liver and metastatic tumor in both control and experimental groups were observed and recorded. The metastatic tumor and the liver tissue were sectioned and stained with hematoxylin-eosin staining to demonstrate the characteristic in morphological changes, the Hoechst 33342 fluorescent staining was applied to show and count the rate of apoptotic cell, and the in situ hybridization technique was used to detect the Bcl-2 and Bax expression. The results showed that the process of carcinogenesis can be divided into three periods: hepatic toxic lesion, hepatic proliferation/cirrhosis and hepatic carcinogenesis. The Hoechst 33342 fluorescent staining showed that the rate of apoptosis in the CG, hepatic toxic lesion, hepatic proliferation/ cirrhosis and hepatic carcinogenesis were $6.7 \%, 18.8 \%, 17.4 \%$ and $51.2 \% \mathrm{c} 2=33.62, \mathrm{P}<0.05$ respectively. In situ hybridization showed the yellow positive reaction products of Bcl-2 and Bax located in the nucleus and cytoplasm of cell in diffusive distribution. The average optical densities of Bcl-2 and Bax expression were $0.1697 \pm 0.0101$ and $0.1383 \pm 0.0093$ in the control group, $0.1431 \pm 0.0072$ and $0.1523 \pm 0.0103$ in hepatic toxic lesion, $0.1261 \pm 0.0164$ and $0.1639 \pm 0.0133$ in hepatic proliferation/cirrhosis, $0.1034 \pm 0.0124$ and $0.1785 \pm 0.0191$ in hepatic carcinogenesis, indicating that the expression of Bcl- 2 decreased, but that of Bax increased with the development of liver cancer in experimental groups. In DEN induced liver cancer, the origination and development of liver cancer were accompanied with proliferation and abnormal apoptosis, which was related to the abnormal expression of gene Bcl-2 and Bax.

KEY WORDS: Primary hepatic carcinoma; Apoptosis; Bcl-2; Bax; Rats.

\section{INTRODUCTION}

Primary hepatic carcinoma (PHC) is one of the most common cancers in the five malignant tumors of the world, which has unobvious pathogenesis, rapid progression and is mostly in late stage at clinical diagnosis (Zubaidah et al., 2008). Recent studies have confirmed that tumor development is closely related to the abnormal cell apoptosis of tumor, the broken balance between cell proliferation and apoptosis is an important factor in tumorigenesis (Chen et al., 2001; Kitamura et al., 1998; Cheng et al., 1997).

Currently two types of apoptosis-related genes are found, which are promoting apoptosis and inhibition of apoptosis genes (Cleveland \& Ihle, 1995). In these genes Bcl-2 and Bax have the most closely related to apoptosis (Wyllie, 1980). In our research the liver cancer model was induced with DEN to simulate and the occurrence and development of human liver cancer. By immunohistochemistry, in situ hybridization and Hoechst 33342 staining method, the variation between Bcl-2 and Bax was detected in the induced cancer model, in order to understand the role and significance in the development of liver cancer cells.

\footnotetext{
Institute of Human Anatomy and Embryology, Binzhou Medical University, Yantai, Shandong, China.

** Department of Human Anatomy, TaiShan Medical University, Taian, China.

Grant support: This research is supported by the Taishan Scholar with affiliation of Otology and Neuroscience Center of BMU, the program of Shandong Provincial Natural Science Foundation of China (No. ZR2011HL055), New Century Excellent Talents in Universities (No. NCET-08-0876), the Medical Science and Technology Development Project of Shandong (No. 2009HW007), Technology project of BinZhou Medical University (No. BY2009KJ12), the special fund of Taishan scholars' construction project and Shandong Provincial Natural Science Foundation of China (No. 2009ZRB01288).
} 


\section{MATERIAL AND METHOD}

Laboratory Methods. Eighty- four Wistar rats weighing about $300 \mathrm{~g}$ in a SPF grade were selected as experimental animals from experimental animal center of Shandong University. 84 rats were used, 72 rats as experimental group, 12 rats as control group. Experimental group had been induced by drinking water containing DEN ( $80 \mathrm{ppm}$, provided by Sigma company) for 12 weeks, and then drank water freely. Control group was given conventional free access to water. In 24 weeks of the experiment, six rats were randomly selected from the experimental group every two weeks. Four rats were respectively selected from the control group in the $4^{\text {th }}, 12^{\text {th }}$ and $24^{\text {th }}$ week. After laparotomy, the form, color, texture of the liver and metastatic tumor in both control and experimental groups were observed and recorded. Portion of the liver and metastatic tumors were fixed by paraformaldehyde, paraffin-embedded. After consecutive paraffin sections and the interval to take tablets, the metastatic tumor and the liver tissue were sectioned and stained with hematoxylin-eosin staining to demonstrate the characteristic in morphological changes, the Hoechst 33342 fluorescent staining was applied to show and count the rate of apoptotic cell (Percentage of apoptosis $=$ (the number of apoptotic cells/ Total cell number) x $100 \%$ ), and the in situ hybridization technique was used to detect the Bcl-2 and Bax expression.

Statistical Analysis. The data were analyzed by SPSS 12.0 software. The rate of apoptosis in rat liver was analyzed by $\mathrm{c} 2$ test with significant differences $(\mathrm{P}<0.01)$. The average optical densities of Bcl-2 and Bax expression were compared with single factor analysis of variance, and the comparison among control group and three periods of experimental group was performed with Dunnett T3.

\section{RESULTS}

The pathological changes of rat liver. In CG, smooth surface and even texture of the liver were observed. Under the microscopy, the liver cells with distinct boundaries arranged radially to the central vein, showing polygonal shape with a big basophilic monokaryon within eosinophilic cytoplasm.

According to the pathological change of liver cells, the process of carcinogenesis can be divided into three periods: hepatic toxic lesion, hepatic proliferation/cirrhosis and hepatic carcinogenesis. (1) In hepatic toxic lesion period (1st w-8th w), no obvious abnormal was observed on the liver surface. Under the microscopy the hepatic lobule was in its integrity, but with diffuse edema, focal necrosis accompanied with inflammatory cell infiltration, some cells in the lobule showed eosinophilic degeneration. The hepatic cell regeneration and fibrous tissue proliferation were also demonstrated. (2) In hepatic proliferation/ cirrhosis period (9th w-16th w), the liver surface became rough with diffusing foci, grey and nearly circular, and its cellular edema became further, the diameter of cell reached $2 \mathrm{~mm}$, the largest was 3 $\mathrm{mm}$. The liver cirrhosis started. Under the microscopy, the liver cells with less atypia proliferated into nodules, and eosinophilic degeneration and hyaline proliferation were observed. (3) In hepatic carcinogenesis period $\left(17^{\text {th }} \mathrm{w}-24^{\text {th }}\right.$ w), the liver was covered by grey nodules in various sizes, and the hemorrhagic spots and necrosis were also seen on the section. Under the microscopy, the liver showed all signs of hepatic cell cancer: cells arranged in cord and lumpish, infiltrated into surrounding liver tissue, and various degrees of fatty degeneration, regional hemorrhage and necrosis were also detected. Peritumoral tissues showed edema, eosinophilic and fatty degeneration, foci of liver cell proliferation, hyperplastic and atypical hyperplasia nodules (Fig. 1).

Apoptosis in liver. The Hoechst 33342 fluorescent staining in experimental group demonstrated hyperchromatic dense granular or massive fluorescent within the apoptotic cells. In cells with typical pathological changes, the nuclear condensation, crescent and apoptotic bodies were also found. In the CG, little abnormal nuclei were demonstrated in the nuclei. In periods of hepatic toxic lesion and hepatic proliferation/cirrhosis, the cells demonstrated karyorrhexis and karyopyknosis. In hepatic carcinogenesis period, the nuclei showed irregular nuclear membrane in various sizes, and a large number of apoptotic bodies. The rate of the apoptotic cells in the hepatic toxic lesion, hepatic proliferation/ cirrhosis and hepatic carcinogenesis period was obviously higher, compared to control group (Fig. 2, Table I).

The expression of Bcl-2 and Bax in rat liver. In situ hybridization showed the yellow positive reaction products of Bcl-2 and Bax located in the nucleus and cytoplasm of cell in diffusive distribution. The average optical density of $\mathrm{Bcl}-2$ expression in the $\mathrm{CG}$ was higher than in each experimental group. And the average optical densities of Bcl-2 expression in three induced cancer periods was gradually decreasing with the extension of time $(\mathrm{F}=70.3297 \mathrm{P}<0.01)$. On the contrary, the average optical density of Bax expression in the CG was lower than in each experimental group. And the average optical densities of Bcl-2 expression in three induced cancer periods was gradually increasing with the extension of time $(\mathrm{F}=20.5623 \mathrm{P}<0.01)$ (Figs. 3 and 4, Table II). 

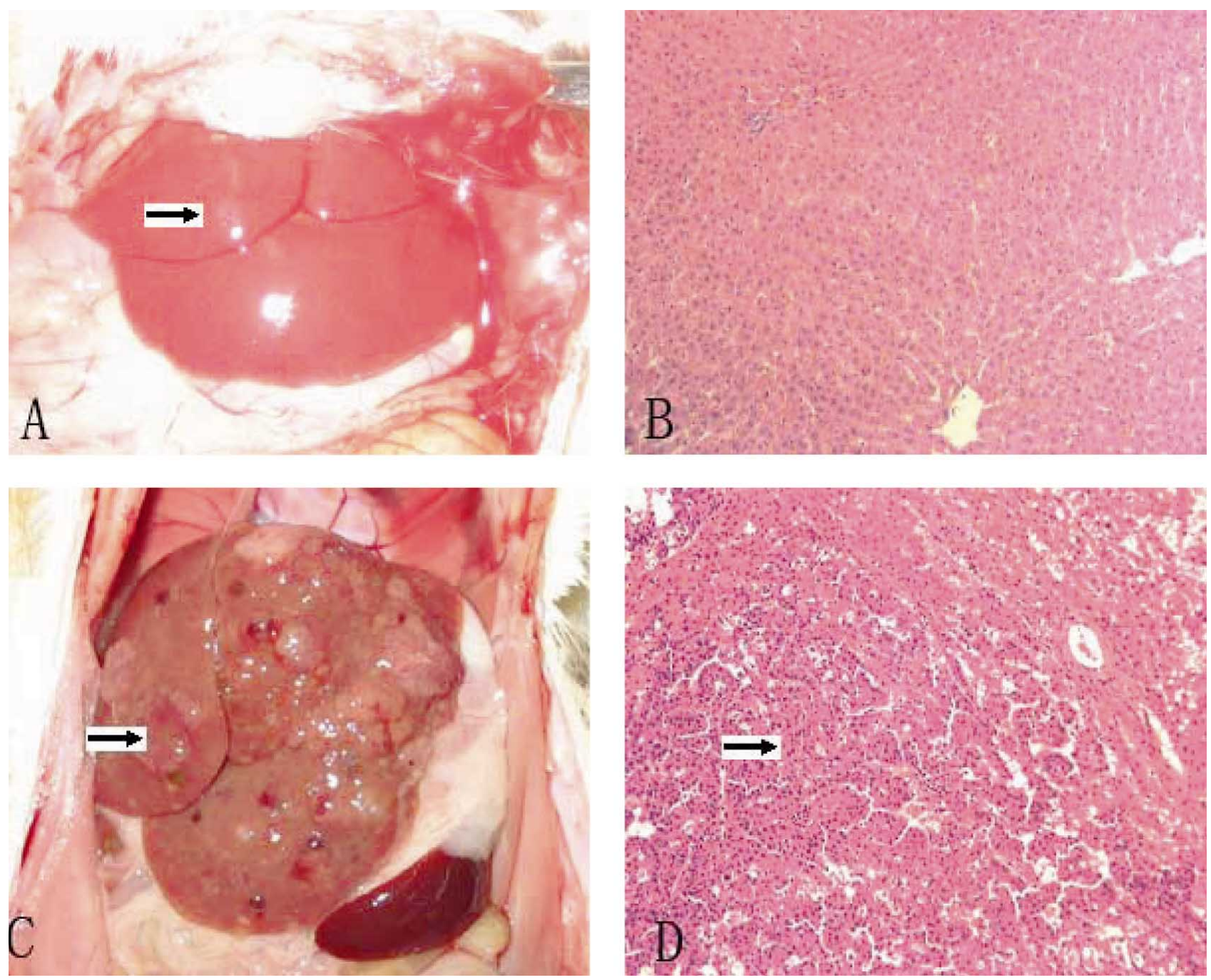

Fig. 1. The pathological changes of rat liver. (A) Morphous of liver at CG: In CG, smooth surface and even texture of the liver were observed (arrows @ demonstrating the normal liver); (B) Hepatic tissue in HE at CG¥100: Under the microscopy, the liver cells with distinct boundaries arranged radially to the central vein, showing polygonal shape with a big basiphilic monokaryon within eosinophilic cytoplasm; (C) In hepatic carcinogenesis period, the liver was covered by grey nodules in various sizes, and the heomorrhagic spots and necrosis were also seen on the section (arrows ${ }^{\circledR}$ demonstrating the liver cancer); (D) Under the microscopy, the liver showed all signs of hepatic cell cancer: cells arranged in cord and lumphish, infiltrated into surrounding liver tissue, and various degrees of fatty degeneration, reginal heomorrhage and necrosis were also detected. Peritumoral tissues showed edema, eosinophilic and fatty degeneration, foci of liver cell proliferation, hyperplastic and atypical hyperplasia nodules (arrows ${ }^{\circledR}$ demonstrating the liver cancer).

Table I. The rate of the apoptotic cells.

\begin{tabular}{lc}
\hline Group & $\begin{array}{c}\text { The rate of the } \\
\text { apoptotic cells }(\%)\end{array}$ \\
\hline CG & 6.21 \\
Hepatic toxic lesion period & $17.42^{*}$ \\
Hepatic proliferation/ cirrhosis period & $18.89^{*}$ \\
Hepatic carcinogenesis period & $51.25^{*}$ \\
\hline * Compared with CG c2 test c2 $=33.62, \mathrm{P}<0.01$ &
\end{tabular}



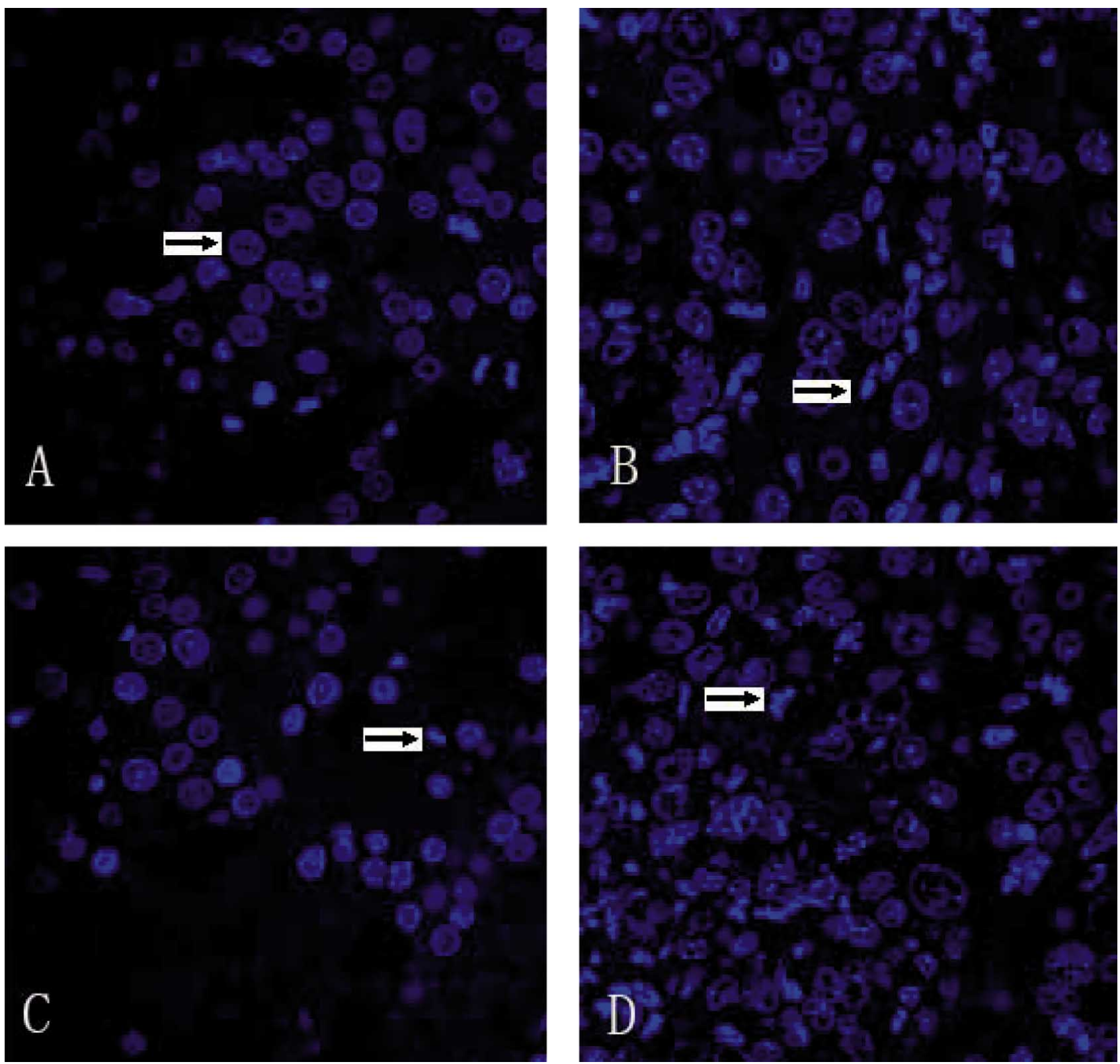

Fig. 2. Apoptosis in rat liver. Hepatic tissue Hoechst33342 CGx1000: In the CG, little abnormal nuclei was demonstrated in the nuclei (arrows ${ }^{\circledR}$ demonstrating the masculine expression of Bcl-2 in hepatic cell); (B) Hepatic tissue in hepatic toxic lesion period by Hoechst 33342x1000: arrows 상 demonstrating the apoptotic hepatic cell nucleus; (C) Hepatic tissue in hepatic proliferation/ cirrhosis period by Hoechst 33342 x 1000: arrows $®$ demonstrating the apoptotic hepatic cell nucleus; (D) Hepatic tissue in hepatic carcinogenesis period by Hoechst 33342x1000: In hepatic carcinogenesis period, the nuclei showed irregular nuclear membrane in various sizes, and a large number of apoptotic bodies arrows ${ }^{\circledR}$ demonstrating the apoptotic hepatic cell nucleus.

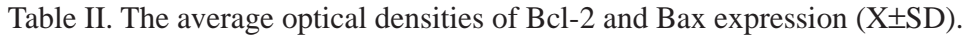

\begin{tabular}{lcc}
\hline Group & Bcl-2 & Bax \\
\hline CG & $0.1697 \pm 0.0101$ & $0.1383 \pm 0.0093$ \\
Hepatic toxic lesion period & $0.1431 \pm 0.0072^{*}$ & $0.1523 \pm 0.0103 *$ \\
Hepatic proliferation/ cirrhosis period & $0.1261 \pm 0.0164 * *$ & $0.1639 \pm 0.0133^{* *}$ \\
Hepatic carcinogenesis period & $0.1034 \pm 0.0124 * * *$ & $0.1785 \pm 0.0191 * * *$ \\
\hline
\end{tabular}

* Compared with CG P<0.01 **Compared with hepatic toxic lesion period $\mathrm{P}<0.01 * * *$ Compared with hepatic carcinogenesis period $\mathrm{P}<0.01$. 

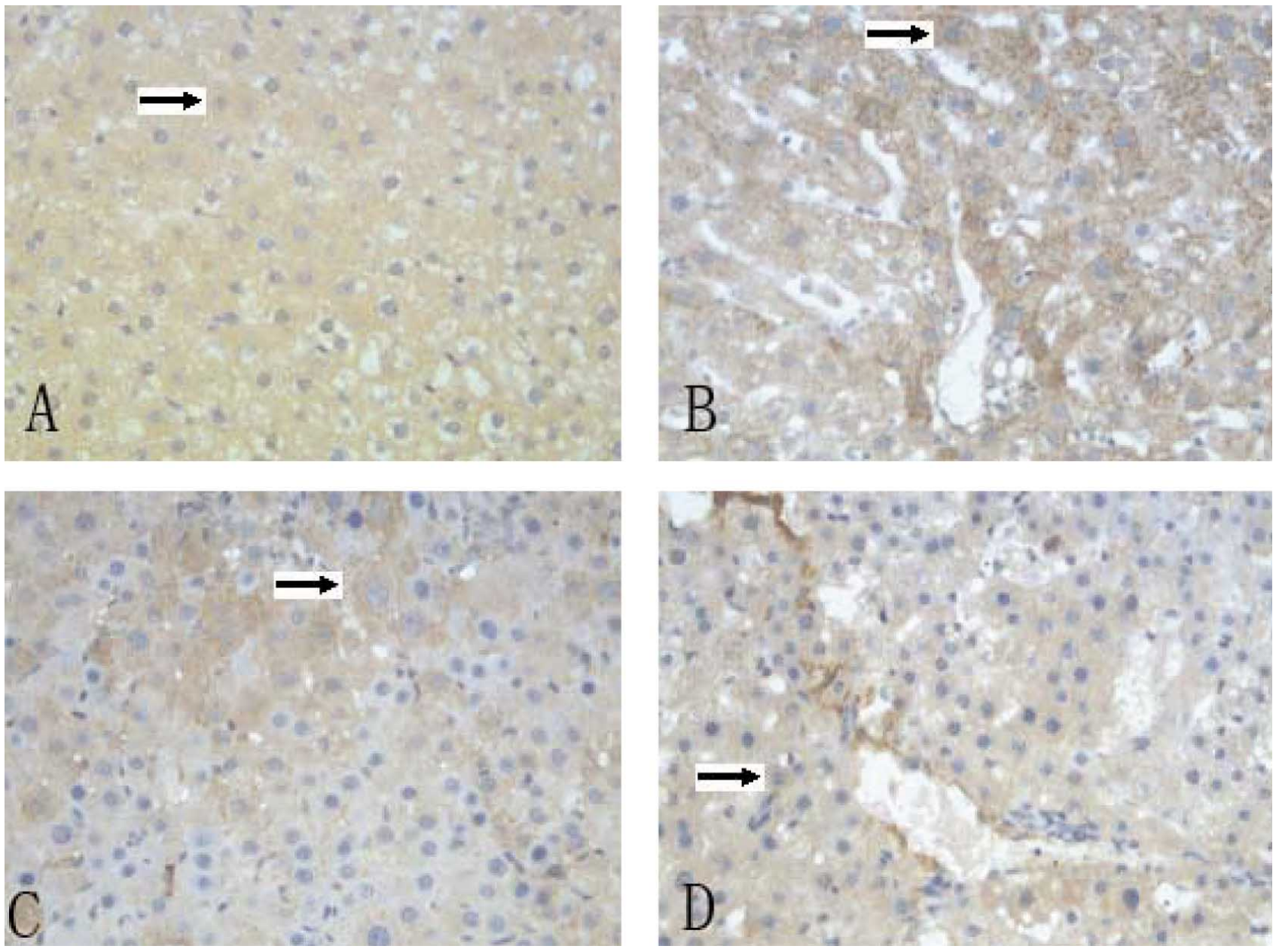

Fig 3. The expression of Bcl-2 in rat liver. (A) The expression of the Bcl-2 in situ hybridization in rat liver CGDABx400: arrows ${ }^{\circledR}$ demonstrating the normal hepatic cell nucleus; (B) The expression of the Bcl-2 in situ hybridization in rat liver. Hepatic toxic lesion period DABx400: arrows ${ }^{\circledR}$ demonstrating the masculine expression of Bcl-2 in hepatic cell; (C) The expression of the Bcl-2 in situ hybridization in rat liver DABx400: arrows ${ }^{\circledR}$ demonstrating the masculine expression of Bcl-2 in hepatic cell;(D) The expression of the Bcl-2 in situ hybridization in rat liver. Hepatic carcinogenesis period DABx400: arrows ${ }^{\circledR}$ demonstrating the masculine expression of Bcl-2 in hepatic cell.

\section{DISCUSSION}

In the course of PHC, selecting the appropriate liver cancer model is an extremely important part of research (Kawasaki et al., 2001). Although many kinds of liver cancer model are established successfully, induced method and induced reagent were different, but it is very difficult to make an animal model of liver cancer similar to the human liver cancer process. After careful consideration we established the rat liver model successfully which was induced by drinking water containing DEN. It has many advantages. First of all, this method is simple operated, and has a short cycle, high rate, high specificity, low mortality rates of induced cancer. Secondly, it is similar to the process and characteristics of human liver cancer, which make up for the lack of clinical specimens. Because the obvious liver cirrhosis in the carcinogenesis process appeared which is like the feature of human liver cancer happened on the basis of liver cirrhosis (Adida et al., 1998; Antonsson \& Martinou, 2000; Guo et al., 2001). In the end, this model experienced three induced cancer periods that was like the development of human liver cancer. In the study of liver cancer model, the liver cells appeared toxic reaction in hepatic toxic lesion period (Ke et al., 2001), with diffuse edema, some cells in the lobule showed eosinophilic degeneration. Under the microscopy the hepatic lobule was in its integrity, but focal necrosis accompanied with inflammatory cell infiltration. The hepatic cell regeneration and fibrous tissue proliferation 

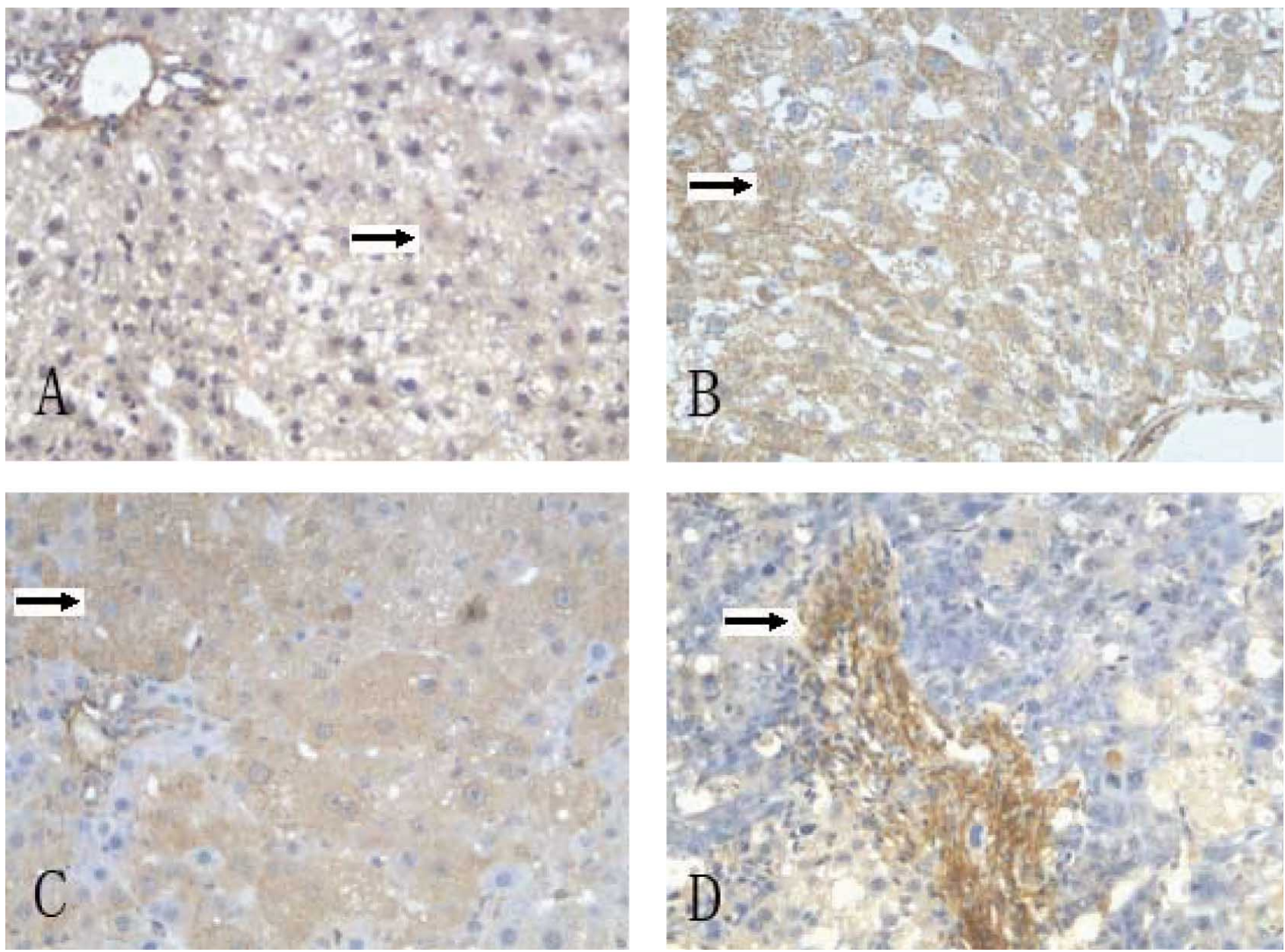

Fig 4. The expression of Bax in rat liver. (A) The expression of the Bax in situ hybridization in rat liver. CGDAB $x$ 400: arrows ${ }^{\circledR}$ demonstrating the masculine expression of Bax in hepatic cell; (B) The expression of the Bax in situ hybridization in rat liver. Hepatic toxic lesion period DABx400: arrows ${ }^{\circledR}$ demonstrating the masculine expression of Bax in hepatic cell; (C) The expression of the Bax in situ hybridization in rat liver. Hepatic proliferation/ cirrhosis period DAB x 400: arrows ${ }^{\circledR}$ demonstrating the masculine expression of Bax in hepatic cell; (D) The expression of the Bax in situ hybridization in rat liver. Hepatic carcinogenesis period DAB x 400: arrows ${ }^{\circledR}$ demonstrating the masculine expression of Bax in hepatic cell.

were also demonstrated. In hepatic proliferation/cirrhosis period, the liver cellular edema became further. Under the microscopy, the liver cells with less atypia proliferated into nodules, and eosinophilic degeneration and hyaline proliferation were observed. The liver cirrhosis appeared. After the $17^{\text {th }}$ week, the liver showed all signs of hepatic cell cancer, Peritumoral tissues showed edema, eosinophilic and fatty degeneration, foci of liver cell proliferation, hyperplastic and atypical hyperplasia nodules. On the basis of the pathological changes we would see that the process of cancer induced got close to the feature and course of mankind liver cancer. In a word, we think that the rat liver model which was induced by drinking water containing DEN was a kind of ideal model.
Apoptosis is a kind of adjusted form of normal cell and an important performance of physiologic function (Oda et al., 2000). From these research, it is indicated that tumor is not only a disease of abnormal hyperplasy and prosoplasia, but also an illness of abnormal apoptosis (Wang et al., 1996; Reed et al., 1996; Oltvai et al., 1993). The abnormality of apoptosis and its controlling gene take part in the development of the tumor (Xiao et al., 2007). Apoptosis is the fundamental feature of the liver cellular damage which is through the mortuus acceptor pathway (Paradiso et al., 2001). In our study, by the hoechst 33342 fluorescent staining we can see the difference between the normal cell and apoptosis cell. The normal cell nucleus was demonstrated regular staining with one accord. But the apoptosis cells 
showed irregular nuclear membrane in various sizes, karyopyknosis, karyorrhexisand a large number of apoptotic bodies. As a result of cell counting, the rate of the apoptotic cells in experimental group was obviously higher than control group. As to the study discovery, no matter in vitro or in vivo, all of the liver tumor exist the apoptosis and the rate of the apoptotic liver cancer cells is obviously higher than the normal liver cells.

Bcl-2 is an anti-apoptotic gene. By inhibiting apoptosis of cancer cell, promoting the proliferation of cancer cell and proliferous cell survival, Bcl-2 can produce cell disequilibrium to cause kinds of tumorigenesis (Williams \& Roberts, 1994; Yin et al., 1994; Fausto \& Campbell, 2010; Ko \& Prives, 1996; Heindryckx et al., 2009). As a contrary, Bax can encourage apoptosis, which belongs to related gene and is distributed over much tissue of human body. In normal condition, Bax can offer apoptotic signal to cell by homodimer. But Bcl-2 can inhibit the development of apoptosis, by the way of competive effect that Bcl-2 and Bax form heterodimer (Terada \& Nakanuma, 1996; Zubaidah et al.). In this study, the average optical density of Bcl-2 at experimental group was higher than it at CG, more importantly it increased with the development of cancer. In contrast the average optical densities of Bax at experimental group was lower than it at control group, and it decreased with the development of cancer. Through statistical analysis, they had significant deviation. It illustrated that $\mathrm{Bcl}-2$ and $\mathrm{Bax}$ were a couple of interactive genes by adverse effect. The average optical density of Bax is close to survival time of liver cancer. It indicates that Bcl-2 and Bax respectively can inhibit and promote apoptosis. They have an important part of modulation in the development of liver cancer.

At present, there are lots of markers of PHC in clinic, but we can not diagnose all kinds of liver cancer by a special marker. To study and research these markers will have a significant influence to early diagnosis, cure and prognosis of liver cancer.

\section{ACKNOWLEDGEMENTS}

This research is supported by the Taishan Scholar with affiliation of Otology and Neuroscience Center of BMU, the program of Shandong Provincial Natural Science Foundation of China (No. ZR2011HL055), New Century Excellent Talents in Universities (No. NCET-08-0876), the Medical Science and Technology Development Project of Shandong (No. 2009HW007), Technology project of BinZhou Medical University (No. BY2009KJ12), the special fund of Taishan scholars' construction project and Shandong Provincial Natural Science Foundation of China (No. 2009ZRB01288). We thank all the members of this team for their hard work and invaluable assistance with the studies.

LIU, H.; ZHANG, L.; CHEN, S.; WANG, Z.; HUANG, F. \& WANG, D. El rol y la importancia de Bcl-2 y Bax en el carcinoma hepático. Int. J. Morphol., 30(4):1466-1473, 2012.

RESUMEN: Este estudio tuvo como objetivo observar la regularidad de la apoptosis en células del hígado y la expresión de apoptosis relacionada con los genes Bcl-2 y Bax en el cáncer inducido, además de explorar la relación entre apoptosis y desarrollo de cáncer hepático. Fueron utilizadas 84 ratas, 72 como grupo experimental inducido con el consumo de agua conteniendo DEN, y 12 como grupo de control (CG). Después de la laparotomía, la forma, color, textura del hígado, y del tumor metastásico fueron observadas y registradas en ambos grupos. El tumor metastásico y el tejido hepático fueron seccionados y teñidos con H-E para demostrar la característica de los cambios morfológicos; se aplicó la tinción fluorescente Hoechst 33342 para mostrar y contar la frecuencia de las células apoptóticas, y se utilizó la técnica de hibridación in situ para detectar la expresión de Bcl-2 y Bax. Los resultados mostraron que el proceso de carcinogénesis se puede dividir en tres etapas: lesión hepática tóxica, proliferación hepática/cirrosis hepática y carcinogénesis. La tinción fluorescente Hoechst 33342 mostró que la tasa de apoptosis en el CG, lesión hepática tóxica, proliferación hepática/cirrosis hepática y carcinogénesis fue de $6,7 \%, 18,8 \%$, $17,4 \%$ y $51,2 \%$ (c2 = 33,62, P <0,05), respectivamente. La hibridación in situ mostró reacción positiva de productos amarillos de Bcl-2 y Bax en el núcleo y citoplasma de la célula en distribución difusa. Las densidades ópticas medias de la expresión de Bcl-

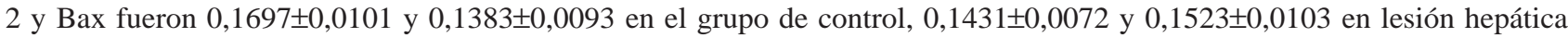

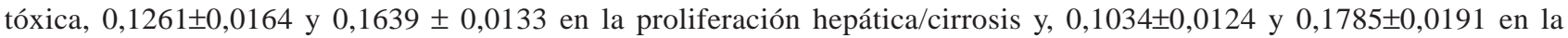
carcinogénesis hepática, lo que indica que la expresión de Bcl-2 se redujo, pero que el Bax aumentó con el desarrollo de cáncer de hígado en los grupos experimentales. En el cáncer hepático inducido por DEN, el origen y desarrollo de cáncer hepático fueron acompañados con proliferación anormal y apoptosis, las cuales se relacionaron con la expresión anormal de los genes Bcl-2 y Bax.

PALABRAS CLAVE: Carcinoma hepático primario; Apoptosis; Bcl-2; Bax; Ratas. 


\section{REFERENCES}

Adida, C.; Berrebi, D.; Peuchmaur, M.; Reyes-Mugica, M. \& Altieri, D. C. Anti-apoptosis gene, survivin, and prognosis of neuroblastoma. Lancet, 351(9106):882-3, 1998.

Antonsson, B. \& Martinou, J. C. The Bcl-2 protein family. Exp. Cell Res., 256(1):50-7, 2000.

Chen, G. G.; Lai, P. B.; Chak, E. C.; Xu, H.; Lee, K. M. \& Lau, W. Y. Immunohistochemical analysis of pro-apoptotic Bid level in chronic hepatitis, hepatocellular carcinoma and liver metastases. Cancer Lett., 172(1):75-82, 2001.

Cheng, E. H.; Kirsch, D. G.; Clem, R. J.; Ravi, R.; Kastan, M. B.; Bedi, A.; Ueno, K. \& Hardwick, J. M. Conversion of Bcl-2 to a Bax-like death effector by caspases. Science, 278(5345):1966-8, 1997.

Cleveland, J. L. \& Ihle, J. N. Contenders in FasL/TNF death signaling. Cell, 81(4):479-82, 1995.

Fausto, N. \& Campbell, J. S. Mouse models of hepatocellular carcinoma. Semin. Liver Dis., 30(1):87-98, 2010.

Guo, B.; Godzik, A. \& Reed, J. C. Bcl-G, a novel pro-apoptotic member of the Bcl-2 family. J. Biol. Chem., 276(4):2780-5, 2001.

Heindryckx, F.; Colle, I. \& Van Vlierberghe, H. Experimental mouse models for hepatocellular carcinoma research. Int. J. Exp. Pathol., 90(4):367-86, 2009.

Kawasaki, H.; Toyoda, M.; Shinohara, H.; Okuda, J.; Watanabe, I.; Yamamoto, T.; Tanaka, K.; Tenjo, T. \& Tanigawa, N. Expression of survivin correlates with apoptosis, proliferation, and angiogenesis during human colorectal tumorigenesis. Cancer, 91(11):2026-32, 2001.

Ke, N.; Godzik, A. \& Reed, J. C. Bcl-B, a novel Bcl-2 family member that differentially binds and regulates Bax and Bak. J. Biol. Chem., 276(16):12481-4, 2001.

Kitamura, T.; Watanabe, S. \& Sato, N. Liver regeneration, liver cancers and cyclins. J. Gastroenterol. Hepatol., 13 Suppl:S969, 1998.

Ko, L. J. \& Prives, C. p53: puzzle and paradigm. Genes Dev., 10(9):1054-72, 1996.

Oda, E.; Ohki, R.; Murasawa, H.; Nemoto, J.; Shibue, T.; Yamashita, T.; Tokino, T.; Taniguchi, T. \& Tanaka, N. Noxa, a BH3-only member of the Bcl-2 family and candidate mediator of p53induced apoptosis. Science, 288(5468):1053-8, 2000.

Oltvai, Z. N.; Milliman, C. L. \& Korsmeyer, S. J. Bcl-2 heterodimerizes in vivo with a conserved homolog, Bax, that accelerates programmed cell death. Cell, 74(4):609-19, 1993.
Paradiso, A.; Simone, G.; Lena, M. D.; Leone, B.; Vallejo, C.; Lacava, J.; Dellapasqua, S.; Daidone, M. G. \& Costa. A. Expression of apoptosis-related markers and clinical outcome in patients with advanced colorectal cancer. Br. J. Cancer, 84(5):651-8, 2001.

Reed, J. C.; Miyashita, T.; Takayama, S.; Wang, H. G.; Sato, T.; Krajewski, S.; Aimé-Sempé, C.; Bodrug, S.; Kitada, S. \& Hanada, M. BCL-2 family proteins: regulators of cell death involved in the pathogenesis of cancer and resistance to therapy. J. Cell Biochem., 60(1):23-32, 1996.

Terada, T. \& Nakanuma, Y. Expression of apoptosis, proliferating cell nuclear antigen, and apoptosis-related antigens (bcl-2, cmyc, Fas, Lewis(y) and p53) in human cholangiocarcinomas and hepatocellular carcinomas. Pathol. Int., 46(10):764-70, 1996.

Wang, K.; Yin, X. M.; Chao, D. T.; Milliman, C. L. \& Korsmeyer, S. J. BID: a novel BH3 domain-only death agonist. Genes Dev., 10(22):2859-69, 1996.

Williams, N. G. \& Roberts, T. M. Signal transduction pathways involving the Raf proto-oncogene. Cancer Metastasis Rev., 13(1):105-16, 1994.

Wyllie, A. H. Glucocorticoid-induced thymocyte apoptosis is associated with endogenous endonuclease activation. Nature, 284(5756):555-6, 1980.

Xiao, Y.; Zhang, X. F,; Jin, X. M.; Zhang, J. S. \& Jia, C. Q. Protection of GM-1 on rat retinal ischemia-reperfusion injury. Chinese Journal of Ocular Trauma and Occupational Eye Disease (With Ophthalmic Surgery), 29(6):401-5, 2007.

Yin, X. M.; Oltvai, Z. N, \& Korsmeyer, S. J. BH1 and BH2 domains of $\mathrm{Bcl}-2$ are required for inhibition of apoptosis and heterodimerization with Bax. Nature, 369(6478):321-3, 1994.

Zubaidah, R. M.; Tan, G. S.; Tan, S. B.; Lim, S. G.; Lin, Q. \& Chung, M. C. 2-D DIGE profiling of hepatocellular carcinoma tissues identified isoforms of far upstream binding protein (FUBP) as novel candidates in liver carcinogenesis. Proteomics, 8(23-24):5086-96, 2008.

Correspondence to:

Professor Huang Fei

Institute of Human Anatomy and Embryology

Binzhou Medical University

Yantai, Shandong

CHINA

Email: hfei22518@163.com

Received: 05-06-2012

Accepted: 07-08-2012 